\title{
UPAYA MENINGKATKAN KEMAMPUAN PEMAHAMAN MATEMATIKA SISWA DENGAN MODEL PEMBELAJARAN KOOPERATIF TIPE THINK PAIR SHARE MATERI BENTUK ALJABAR
}

\author{
Elsa Br. Tarigan \\ Universitas Katolik Santo Thomas, Medan; \\ elsatarigan10@gmail.com
}

\begin{abstract}
Abstrak. Tujuan penelitian ini adalah untuk: (1) mengetahui tingkat kemampuan pemahaman matematika siswa kelas VII SMP Negeri 2 Pancur Batu sebelum dan sesudah menggunakan model pembelajaran kooperatif tipe Think-Pair-Share, (2) mengidentifikasi penerapan model pembelajaran kooperatif tipe Think-Pair-Share dalam upaya meningkatkan kemampuan pemahaman matematika siswa pada materi operasi bentuk aljabar. Jenis penelitian ini adalah Classroom Action Research. Subjek penelitian ini adalah seluruh siswa kelas VII-2 SMP Negeri 2 Pancur Batu. Waktu pelaksanaan semester 1 Tahun Ajaran 2017/2018. Teknik pengumpulan data meliputi teknik tes dan non tes. Penelitian dilakukan dalam dua siklus. Tingkat kemampuan pemahaman matematika siswa pada siklus I sebesar 56,67\% sedangkan pada siklus II diperoleh sebesar $76,67 \%$. Hasil penelitian ini menunjukkan adanya peningkatan kemampuan pemahaman matematika siswa dari siklus I ke siklus II yaitu sebesar $20 \%$. Peningkatan aktivitas guru terlihat dari rata-rata persentase aktivitas guru pada siklus I adalah 57,14\% meningkat pada siklus II menjadi $77,14 \%$. Peningkatan aktivitas siswa terlihat dari rata-rata persentase aktivitas siswa pada siklus I adalah $61,42 \%$ meningkat pada siklus II menjadi $85,71 \%$. Berdasarkan hasil yang diperoleh dari penelitian ini disimpulkan bahwa dengan model pembelajaran kooperatif tipe ThinkPair-Share dapat meningkatkan kemampuan pemahaman matematika siswa di kelas VII SMP Negeri 2 Pancur Batu.
\end{abstract}

Kata Kunci. Model Kooperatif, Think-Pair-Share, Pemahaman

Abstract. The purpose of this study was to: (1) determine the level of mathematical comprehension ability of class VII students of Pancur Batu 2 Middle School before and after using the Think-Pair-Share type cooperative learning model, (2) identify the application of Think-Pair-Share type

Cartesius: Jurnal Pendidikan Matematika Vol. 2, No. 1

CProdi Pendidikan Matematika Universitas Katolik Santo Thomas 
cooperative learning models in an effort to improve students' mathematical understanding skills in algebraic form operating material. This type of research is Classroom Action Research. The subjects of this study were all students of class VII-2 of Pancur Batu 2 of Junior High School. Time for implementation of semester 1 of the Academic Year 2017/2018. Data collection techniques include test and non-test techniques. The study was conducted in two cycles. The level of mathematics comprehension ability of students in the first cycle was $56.67 \%$ while the second cycle was $76.67 \%$. The results of this study indicate an increase in students' mathematical understanding skills from cycle I to cycle II which is equal to $20 \%$. Increased teacher activity can be seen from the average percentage of teacher activity in the first cycle is $57.14 \%$, increasing in the second cycle to $77.14 \%$. Increased student activity can be seen from the average percentage of student activity in the first cycle is $61.42 \%$, increasing in the second cycle to $85.71 \%$. Based on the results obtained from this study, it was concluded that the cooperative learning model of the Think-Pair-Share type could improve students' mathematical comprehension skills in class VII of Pancur Batu 2 of Junior High School.

Keywords. Cooperative model, Think-Pair-Share, understanding

\section{PENDAHULUAN}

Pendidikan merupakan suatu proses yang dilakukan secara sadar untuk mewujudkan suasana belajar agar peserta didik secara aktif mengembangkan potensi yang dimilikinya. Pelaksanaan pendidikan di Indonesia tidak terlepas dari penerapan kurikulum yang senantiasa disesuaikan dengan perkembangan zaman. Salah satu lembaga pendidikan yang menyelenggarakan proses belajar mengajar adalah sekolah. Sekolah mempunyai peranan penting dalam pemberian pengetahuan dan keterampilan kepada siswa. Peranan tersebut diharapkan dapat menghasilkan siswa yang berkualitas tinggi di bidang ilmu pengetahuan.

Salah satu bidang studi yang sangat penting yang diperlukan dalam dunia pendidikan baik dalam menyelesaikan masalah adalah matematika. Pelaksanaan pembelajaran matematika hendaknya dapat merangsang siswa untuk memperoleh kompetensi yang diharapkan. Salah satu kompetensi tersebut adalah meningkatkan kemampuan pemahaman siswa. Pemahaman siswa merupakan hal yang substansial dan sangat penting dalam proses

Cartesius: Jurnal Pendidikan Matematika Vol. 2, No. 1

CProdi Pendidikan Matematika Universitas Katolik Santo Thomas 
pembelajaran. Hal ini disebabkan keberhasilan suatu proses pembelajaran dicerminkan oleh pemahaman siswa terhadap materi yang diajarkan, yang kemudian diwujudkan dalam hasil kemampuan pemahaman yang tinggi atau rendah. Semakin luas pemahaman tentang ide atau gagasan matematika yang dimiliki oleh seorang siswa, maka akan semakin bermanfaat dalam menyelesaikan suatu permasalahan yang dihadapinya. Kata kunci yang menjadi awal keberhasilan pembelajaran matematika adalah pemahaman matematis [1].

Pentingnya mempelajari matematika juga disebutkan oleh NCTM bahwa dengan kemampuan matematika akan membuka pintu untuk masa depan yang produktif. Semua siswa harus memiliki kesempatan dan dukungan yang diperlukan untuk belajar matematika [2].

Meskipun matematika sangat penting dan perlu diajarkan, namun sampai saat ini matematika termasuk bidang studi yang dianggap sulit untuk dipelajari dibandingkan dengan bidang studi lain. Dalam materi matematika yang diajarkan memiliki peranan penting dalam menyelesaikan persoalan dalam kehidupan sehari-hari, oleh karena itu siswa diberikan dasar- dasar untuk memahami matematika ini [3]. Russeffendi menyatakan bahwa terdapat banyak anak-anak yang setelah belajar matematika bagian yang sederhanapun banyak yang tidak dipahaminya, banyak konsep yang dipahami secara keliru. Matematika dianggap sebagai ilmu yang sukar [4]. Kesulitan siswa dalam belajar matematika, karena kebanyakan dari mereka belum memahami maksud dari materi yang akan dipelajari. Satu diantara materi matematika yang diajarkan di tingkat Sekolah Menengah Pertama (SMP) adalah materi operasi bentuk aljabar.

Berdasarkan hasil wawancara yang telah dilakukan dengan guru bidang studi matematika kelas VII di Sekolah SMP Negeri 2 Pancur Batu yaitu Bapak P. Kaban, diperoleh keterangan bahwa tingkat kemampuan pemahaman matematika siswa masih tergolong rendah atau $70 \%$ di bawah standar ketuntasan KKM $(<70)$. Hal ini disebabkan karena kurangnya kesiapan siswa dalam proses pembelajaran, siswa belum percaya diri dalam

Cartesius: Jurnal Pendidikan Matematika Vol. 2, No. 1

CProdi Pendidikan Matematika Universitas Katolik Santo Thomas 
menyampaikan gagasan, dan siswa kesulitan dalam memahami konsep, sehingga siswa membutuhkan waktu yang cukup lama dalam menyelesaikan soal-soal yang diberikan guru.

Selain itu, penulis juga melakukan minitest untuk mengetahui tingkat kemampuan pemahaman matematika siswa dengan memberikan 5 butir soal kemampuan pemahaman matematika di kelas VII SMP Negeri 2 Pancur Batu. Dari hasil analisis jawaban siswa, diperoleh rata-rata nilai kemampuan pemahaman matematika siswa sebesar 28,5 dengan nilai tertinggi 63 dan nilai terendah 0. Dari 30 siswa kelas VII SMP Negeri 2 Pancur Batu, ternyata 27 siswa yang mengikuti tes. Dari 27 siswa tersebut, tidak ada siswa (0 \%) yang mendapat nilai di antara 81-100 dengan kategori sangat baik, 1 orang siswa (4\%) yang mendapat nilai di antara 61-80 dengan kategori baik, 4 orang siswa (15\%) yang mendapat nilai di antara 41-60 dengan kategori cukup baik, 9 orang siswa (33\%) yang mendapat nilai di antara 21-40 dengan kategori kurang baik, dan 13 orang siswa (48\%) yang mendapat nilai di antara 0-20 dengan kategori tidak baik. Hal ini menunjukkan bahwa tingkat kemampuan pemahaman matematika siswa di kelas VII SMP Negeri 2 Pancur Batu pada pokok bahasan operasi bentuk aljabar masih tergolong rendah.

Salah satu soal kemampuan pemahaman matematika yang diberikan adalah Di sebuah meja makan terdapat 5 sendok, 5 piring, dan 5 gelas. Budi mengambil 1 piring dan 1 sendok kemudian menaruhnya di rak piring. Lalu Abi menaruh 2 buah piring, 3 sendok dan 1 gelas di atas meja itu. Maka berapakah jumlah masing-masing peralatan makan yang tersedia di meja tersebut? Atas pertanyaan tersebut, salah satu dari siswa menuliskan jawabannya sebagai berikut:

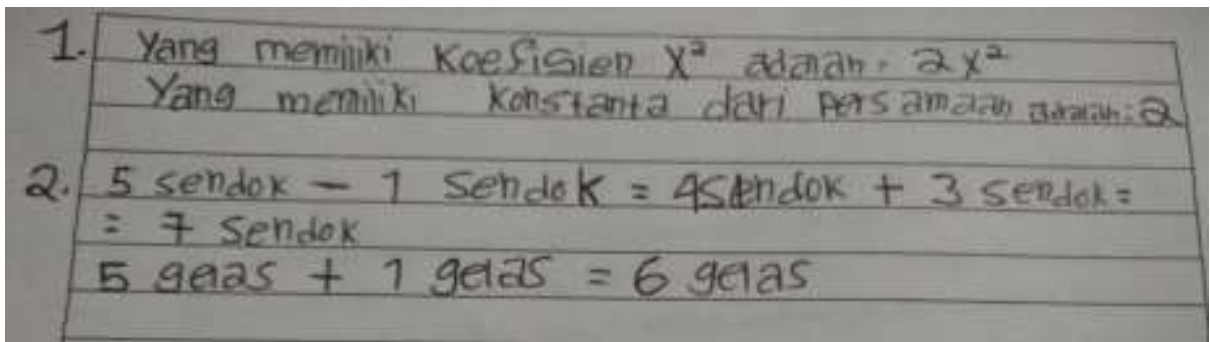

Gambar 1. Lembar Jawaban Minitest Siswa

Cartesius: Jurnal Pendidikan Matematika Vol. 2, No. 1

CProdi Pendidikan Matematika Universitas Katolik Santo Thomas 
Dari jawaban tersebut di atas menunjukkan bahwa siswa tidak mampu mengubah soal cerita ke dalam model matematika. Hal ini menunjukkan bahwa kemampuan pemahaman matematika (translasi) siswa masih rendah. Oleh karena itu, perlu dilakukan upaya untuk meningkatkan kemampuan pemahaman matematika siswa di kelas VII SMP Negeri 2 Pancur Batu.

Pemilihan model atau metode pembelajaran juga berdampak pada rendahnya tingkat kemampuan pemahaman siswa. Seperti halnya di sekolah SMP Negeri 2 Pancur Batu, metode yang digunakan masih didominasi metode ceramah dan tanya jawab. Hal ini menyebabkan siswa cenderung pasif dalam mengikuti pembelajaran. Padahal keterlibatan aktif siswa akan mendorong siswa untuk lebih mengerti apa yang mereka lakukan sehingga memberikan pemahaman yang lebih baik.

Untuk mengatasi permasalahan di atas, guru dapat memilih dan menerapkan model pembelajaran yang dapat memicu siswa lebih cepat dan aktif sehingga dapat meningkatkan kemampuan siswa dalam memahami materi pelajaran. Salah satu model pembelajaran yang dapat digunakan untuk meningkatkan kemampuan pemahaman matematika adalah model pembelajaran kooperatif tipe Think-Pair-Share. Menurut Arends model pembelajaran kooperatif tipe thinkpair-share atau berfikir-berpasanganberbagi merupakan jenis pembelajaran kooperatif yang diracang untuk mempengaruhi pola interaksi siswa [5].

Berdasarkan latar belakang di atas, peneliti merasa perlu untuk merealisasikan upaya tersebut dalam suatu penelitian dengan judul Upaya Meningkatkan Kemampuan Pemahaman Matematika Siswa Dengan Model Pembelajaran Kooperatif Tipe Think-Pair-Share Materi Bentuk Aljabar.

\section{METODE}

Penelitian ini dilaksanakan dengan menggunakan pendekatan campuran, yaitu kualitatif dan kuantitatif. Sedangkan metode Penelitian yang digunakan adalah Penelitian Tindakan Kelas (PTK) atau Classroom Action

Cartesius: Jurnal Pendidikan Matematika Vol. 2, No. 1

CProdi Pendidikan Matematika Universitas Katolik Santo Thomas 
Research. Secara sederhana siklus pelaksanaan penelitian tindakan kelas disajikan sebagai berikut:

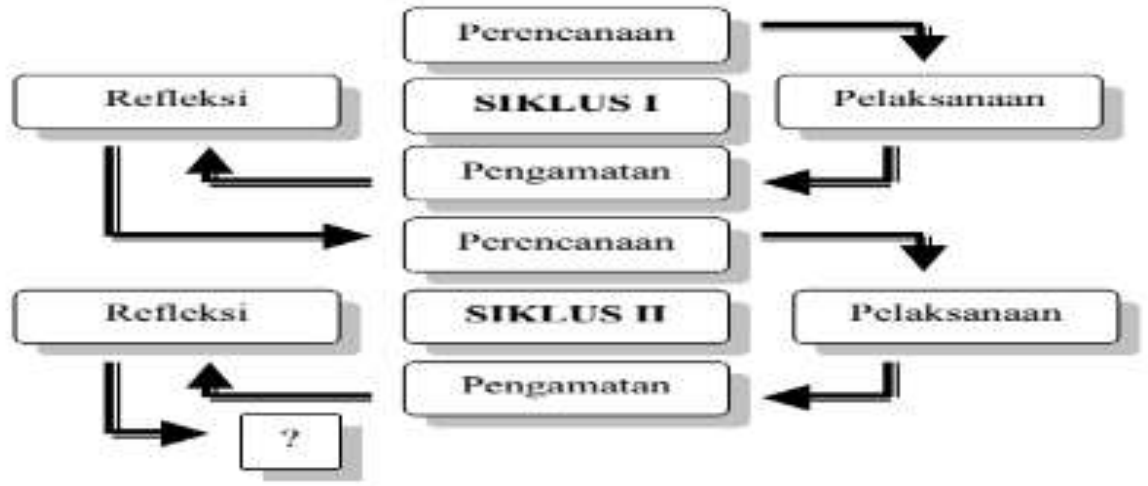

Gambar 2. Siklus Penelitian Tindakan Kelas

Penelitian ini dilaksanakan di kelas VII SMP Negeri 2 Pancur Batu, pada semester ganjil tahun pelajaran 2017/2018. Subjek penelitian ini adalah seluruh siswa kelas VII-2 SMP Negeri 2 Pancur Batu yang berjumlah 30 orang siswa. Objek penelitian ini adalah: (a) peningkatan kemampuan pemahaman matematika siswa kelas VII SMP Negeri 2 Pancur Batu dengan model pembelajaran kooperatif tipe Think-Pair-Share, (b) proses tindakan yang dilakukan yaitu penerapan model pembelajaran kooperatif tipe ThinkPair-Share.

Adapun jenis data yang digunakan dalam penelitian ini adalah data kualitatif dan data kuantitatif. Teknik pengumpulan data meliputi teknik tes dan nontes. Alat pengumpulan data meliputi tes dan lembar observasi aktivitas siswa dan guru. Tes yang digunakan dalam penelitian ini adalah tes kemampuan prasyarat dan tes kemampuan pemahaman matematika.

Untuk mengetahui ketuntasan belajar siswa (individu) dalam kemampuan pemahaman matematika akan dianalisis dengan rumus sebagai berikut:

$$
\text { KBS }=\frac{\sum \text { skor perolehan }}{\text { skor total }} \times 100
$$

Suatu kelas dikatakan tuntas dalam proses pembelajaran jika di dalam kelas terdapat $75 \%$ siswa yang dapat mencapai nilai KKM yaitu 70. Ketuntasan klasikal dalam penelitian ini akan dianalisis dengan rumus sebagai berikut:

Cartesius: Jurnal Pendidikan Matematika Vol. 2, No. 1

CProdi Pendidikan Matematika Universitas Katolik Santo Thomas 


$$
\mathrm{KK}=\frac{\mathrm{x}}{\mathrm{Z}} \times 100 \%
$$

\section{Keterangan :}

KK = Persentase Ketuntasan Klasikal

$\mathrm{x}$ = Banyaknya siswa yang memperoleh nilai $\geq 75$

$\mathrm{Z}$ = Banyaknya siswa yang mengikuti test

Untuk mengetahui hasil perkembangan lembar aktivitas guru dapat diperoleh dari rumus sebagai berikut :

$$
\text { Nilai guru }=\frac{\text { skor yang di peroleh }}{\text { skor maksimum }} \times 100
$$

Sedangkan hasil perkembangan lembar aktivitas siswa dapat diperoleh dari rumus sebagai berikut:

$$
\text { Nilai siswa }=\frac{\text { skor yang di peroleh siswa }}{\text { skor maksimum }} \times 100
$$

Adapun indikator keberhasilan yang diharapkan dalam penelitian ini, yaitu: (1) Indikator keberhasilan kualitas proses pembelajaran minimal "baik" atau $\geq 61$ dilihat dari lembar observasi aktivitas guru; (2) Indikator keberhasilan perbaikan prilaku siswa (misalnya, aspek motivasi belajar, minat belajar, keaktifan siswa, kerjasama, dan lain-lain) minimal "baik" atau $\geq 61$ dilihat dari lembar observasi aktivitas siswa; (3) Indikator keberhasilan hasil belajar secara klasikal minimal 75\% dari jumlah siswa yang mencapai KKM yang ditetapkan (>70).

\section{HASIL DAN PEMBAHASAN}

Sebelum tindakan siklus I dimulai, siswa diberikan tes kemampuan materi prasyarat. Tes kemampuan materi prasyarat merupakan tes awal yang diberikan sebelum pembelajaran siklus I. Adapun hasil tes kemampuan materi prasyarat ditunjukkan pada tabel berikut:

Tabel 3. Nilai Tes Kemampuan Materi Prasyarat

\begin{tabular}{lc}
\hline \multicolumn{1}{c}{ Kategori nilai } & Nilai \\
\hline Tertinggi & 75 \\
Terendah & 30 \\
Rata-rata & 56,34 \\
Jumlah siswa yang lulus KKM & 19 orang \\
\hline
\end{tabular}

Cartesius: Jurnal Pendidikan Matematika Vol. 2, No. 1

CProdi Pendidikan Matematika Universitas Katolik Santo Thomas 
Jumlah siswa yang tidak lulus KKM

11 orang

Tabel 3 menunjukkan bahwa rata-rata tingkat penguasaan tes kemampuan materi prasyarat adalah 56,34 dengan jumlah siswa yang memiliki penguasaan kemampuan materi prasyarat sebanyak 19 orang (63,33\%) sedangkan jumlah siswa yang belum memiliki penguasaan kemampuan materi prasyarat yang baik sebanyak 11 orang $(36,67 \%)$.

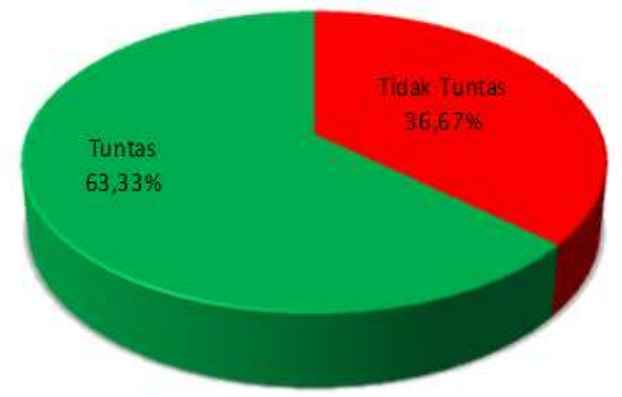

Gambar 3. Persentase Kemampuan Materi Prasyarat

\section{SIKLUS I}

Prosedur yang dilaksanakan pada siklus I terdiri dari empat tahap. Adapun kegiatan-kegiatan yang dilakukan pada masing-masing tahap akan dijelaskan sebagai berikut:

\section{Tahap Perencanaan}

Pada tahap perencanaan tindakan ini, hal-hal yang dilakukan adalah (1) menyusun Rencana Pelaksanaan Pembelajaran (RPP) yang berisikan langkah-langkah kegiatan dalam pembelajaran yang menggunakan model pembelajaran Think-Pair-Share; (2) Menyiapkan perangkat pembelajaran untuk setiap pertemuan seperti: RPP dan LAS; (3) Menyiapkan instrumen penelitian, yaitu tes kemampuan pemahaman matematika; (4) Menyiapkan lembar observasi aktivitas guru dan siswa; (5) Menyiapkan pedoman penskoran.

\section{Tahap Pelaksanaan}

Pada tahap ini, peneliti melaksanakan pembelajaran di kelas dengan menerapkan model pembelajaran kooperatif tipe Think-Pair-Share. Dengan

Cartesius: Jurnal Pendidikan Matematika Vol. 2, No. 1

(CProdi Pendidikan Matematika Universitas Katolik Santo Thomas 
tujuan untuk mengupayakan agar kemampuan pemahaman matematika serta aktivitas siswa mengalami peningkatan. Setelah pelaksanaan pembelajaran siklus I selesai, siswa diberikan tes untuk meningkatkan kemampuan pemahaman matematika siswa yang diperoleh selama pembelajaran pada pertemuan ke-1 dan 2, hasilnya disajikan pada tabel berikut:

Tabel 4. Nilai Tes Kemampuan Pemahaman Matematika Siswa Siklus I

\begin{tabular}{lc}
\hline \multicolumn{1}{c}{ Kategori } & Nilai \\
\hline Tertinggi & 70 \\
Terendah & 30 \\
Rata-rata & 53,33 \\
Jumlah siswa yang lulus KKM & 17 orang \\
Jumlah siswa yang tidak lulus KKM & 13 orang \\
\hline
\end{tabular}

Tabel 4 menunjukkan bahwa rata-rata tingkat kemampuan pemahaman matematika siswa adalah 53,33 dengan jumlah siswa yang memiliki kemampuan pemahaman matematika 17 orang $(56,67 \%)$ dan jumlah siswa yang belum memiliki kemampuan pemahaman matematika yang baik sebanyak 13 orang $(43,33 \%)$.

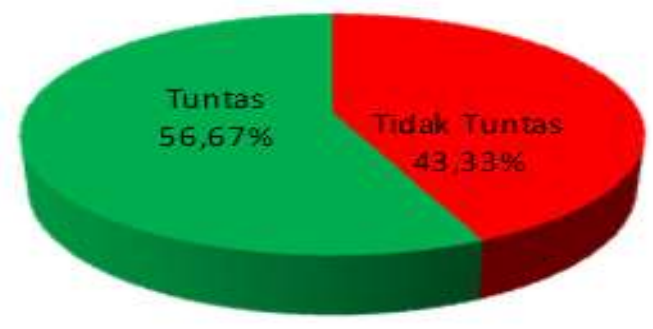

\section{Gambar 4. Persentase Kemampuan Pemahaman Matematika Siswa Siklus I}

Berdasarkan gambar 4 di atas, dapat disimpulkan bahwa siswa belum memiliki tingkat kemampuan pemahaman matematika dengan baik karena masih dibawah $75 \%$ atau ketuntasan klasikal belum tercapai.

\section{Tahap Pengamatan/Observasi}

Aspek yang diamati dalam hal ini adalah aktivitas siswa dan guru selama proses pembelajaran dengan menggunakan lembar observasi. Observasi

Cartesius: Jurnal Pendidikan Matematika Vol. 2, No. 1

CProdi Pendidikan Matematika Universitas Katolik Santo Thomas 
dilakukan oleh guru bidang studi matematika SMP Negeri 2 Pancur Batu. Hasil observasi berupa catatan untuk peneliti sebagai bahan pertimbangan tindakan pada siklus II. Adapun hasil observasi aktivitas guru pada pertemuan ke-1 dan ke-2 adalah disajikan pada tabel berikut:

Tabel 5. Nilai Hasil Observasi Aktivitas Guru Siklus I

\begin{tabular}{crcc}
\hline No. & \multicolumn{1}{c}{ Siklus I } & Persentase & Kriteria \\
\hline 1. & Pertemuan ke-1 & $44 \%$ & Cukup \\
2. & Pertemuan ke-2 & $72 \%$ & Baik \\
3. & Rata-rata nilai & $57,14 \%$ & Cukup \\
\hline
\end{tabular}

Sedangkan hasil observasi aktivitas siswa pada pertemuan ke-1 dan pertemuan ke-2 dapat dilihat pada tabel berikut:

Tabel 6. Nilai Hasil Observasi Aktivitas Siswa Siklus I

\begin{tabular}{crcc}
\hline No. & \multicolumn{1}{c}{ Siklus I } & Persentase & Kriteria \\
\hline 1. & Pertemuan ke-1 & $55 \%$ & Cukup \\
2. & Pertemuan ke-2 & $68,4 \%$ & Baik \\
3. & Rata-rata nilai & $61,42 \%$ & Baik \\
\hline
\end{tabular}

\section{Refleksi}

Berdasarkan indikator kinerja diperoleh bahwa hasil analisis data pada lembar observasi aktivitas guru pada siklus I yaitu 57,14\%; Sementara hasil observasi aktivitas siswa pada siklus I yaitu 61,42\%; Sedangkan data hasil tes kemampuan pemahaman matematika siswa pada siklus I yaitu 56,67\%. Dari nilai observasi dan nilai tes kemampuan pemahaman matematika siswa diperoleh bahwa tindakan siklus I belum mencapai indikator kinerja keberhasilan. Oleh sebab itu, maka perlu dilakukan perbaikan tindakan pada siklus II agar kelemahan dari siklus I tidak terulang pada siklus II.

\section{SIKLUS II}

Pembentukan kelompok pada siklus II berdasarkan hasil tes kemampuan pemahaman matematika siswa pada siklus I. Pelaksanaan siklus II merupakan implementasi dari persiapan atau rancangan yang disusun sebelumnya. Adapun kegiatan-kegiatan yang dilakukan pada masingmasing tahap akan dijelaskan sebagai berikut:

Cartesius: Jurnal Pendidikan Matematika Vol. 2, No. 1

CProdi Pendidikan Matematika Universitas Katolik Santo Thomas 


\section{Tahap Perencanaan}

Tahap perencanaan siklus II dilakukan untuk memperbaiki setiap kesalahan yang terdapat pada siklus I. Perencanaan yang dilakukan sama seperti langkah-langkah perencanaan pada saat akan melaksanakan siklus I.

\section{Tahap Pelaksanaan}

Tindakan ini dilaksanakan sesuai dengan Rencana Pelaksanaan Pembelajaran (RPP) yang berisikan langkah-langkah kegiatan dalam pembelajaran yang menggunakan model pembelajaran kooperatif tipe ThinkPair-Share. Observasi/pengamatan dilakukan di dalam kelas, pada saat pelaksanaan tindakan berlangsung. Setelah pelaksanaan siklus II selesai, siswa diberikan tes selama pembelajaran pada pertemuan ke-1 dan ke-2. Hasilnya disajikan pada tabel berikut:

Tabel 7. Nilai Tes Kemampuan Pemahaman Matematika Siswa Siklus II

\begin{tabular}{|c|c|}
\hline Kategori & Nilai \\
\hline Tertinggi & 80 \\
\hline Terendah & 50 \\
\hline Rata-rata & 71,2 \\
\hline Jumlah siswa yang lulus KKM & 23 orang \\
\hline Jumlah siswa yang tidak lulus KKM & 7 orang \\
\hline
\end{tabular}

Tabel 7 menunjukkan bahwa rata-rata tingkat kemampuan pemahaman matematika siswa adalah 71,2 dengan jumlah siswa yang memiliki kemampuan pemahaman matematika 23 orang $(76,67 \%)$ dan jumlah siswa yang belum memiliki kemampuan pemahaman matematika yang baik sebanyak 7 orang (23,33\%). Jika dianalisis berdasarkan ketuntasannya dapat dilihat pada gambar berikut:

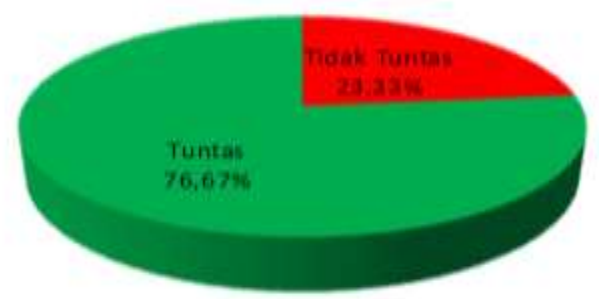

Gambar 5. Persentase Kemampuan Pemahaman Matematika Siswa Siklus II

Cartesius: Jurnal Pendidikan Matematika Vol. 2, No. 1

(CProdi Pendidikan Matematika Universitas Katolik Santo Thomas 
Berdasarkan gambar 5 di atas, dapat disimpulkan bahwa siswa memiliki tingkat kemampuan pemahaman matematika dengan baik atau tingkat keberhasilan belajar (ketuntasan klasikal) sudah di atas 75\%. Hal ini menunjukkan bahwa penerapan model pembelajaran kooperatif tipe ThinkPair-Share dapat meningkatkan kemampuan pemahaman matematika siswa pada pokok bahasan operasi bentuk aljabar di kelas VII SMP Negeri 2 Pancur Batu.

\section{Tahap Pengamatan/Observasi}

Aspek yang diamati pada tahap ini adalah aktivitas siswa dan guru selama proses pembelajaran dengan menggunakan lembar observasi. Adapun hasil pengamatan/observasi aktivitas guru pada pertemuan ke-1 dan ke-2 dapat dilihat pada tabel berikut:

Tabel 8. Nilai Hasil Observasi Aktivitas Guru Siklus II

\begin{tabular}{clcc}
\hline No. & \multicolumn{1}{c}{ Siklus II } & Persentase & Kriteria \\
\hline 1. & Pertemuan ke-1 & $72,8 \%$ & Baik \\
2. & Pertemuan ke-2 & $81,4 \%$ & Sangat Baik \\
3. & Rata-rata nilai & $77,14 \%$ & Baik \\
\hline
\end{tabular}

Sedangkan hasil pengamatan/observasi aktivitas siwa pada pertemuan ke-1 dan pertemuan ke-2 dapat dilihat pada tabel berikut:

Tabel 9. Nilai Hasil Observasi Aktivitas Siswa Siklus II

\begin{tabular}{clcc}
\hline No. & \multicolumn{1}{c}{ Siklus II } & Persentase & Kriteria \\
\hline 1. & Pertemuan ke-1 & $80,5 \%$ & Baik \\
2. & Pertemuan ke-2 & $88,42 \%$ & Sangat Baik \\
3. & Rata-rata nilai & $85,71 \%$ & Sangat Baik \\
\hline
\end{tabular}

Berdasarkan tabel 9 menunjukkan bahwa hasil persentase pengamatan/ observasi aktivitas siswa pada siklus II ada kemajuan yang signifikan.

\section{Refleksi}

Perbaikan yang direncanakan pada siklus II sudah dilaksanakan dengan baik sehingga kekurangan atau kelemahan-kelemahan yang terjadi pada siklus I dapat diatasi dengan baik. Hasil observasi aktivitas guru pada siklus II yaitu $77,14 \%$ dan observasi aktivitas siswa diperoleh nilai 85,71\%. Hasil tes

Cartesius: Jurnal Pendidikan Matematika Vol. 2, No. 1

CProdi Pendidikan Matematika Universitas Katolik Santo Thomas 
kemampuan pemahaman matematika siswa siklus II diperoleh bahwa jumlah siswa yang memiliki kemampuan pemahaman matematika sebanyak 23 orang $(76,67 \%)$ dan jumlah siswa yang belum memiliki kemampuan pemahaman matematika yang baik sebanyak 7 orang (23,33\%). Berdasarkan hasil perolehan ini tingkat keberhasilan belajar (ketuntasan klasikal) siswa memiliki kemampuan pemahaman matematika dengan baik. Dengan peningkatan kemampuan tersebut, maka proses belajar mengajar tidak perlu dilanjutkan ke siklus berikutnya. Hal ini disebabkan karena indikator keberhasilan yang diharapkan sudah tercapai dengan baik. Berdasarkan nilai yang diperoleh dari tes kemampuan materi prasyarat 63,33\% dan tes setiap akhir siklus I yang mengalami peningkatan pada siklus II yaitu dari 56,67\% menjadi 76,67\%. Untuk lebih jelasnya dapat dilihat pada gambar berikut:

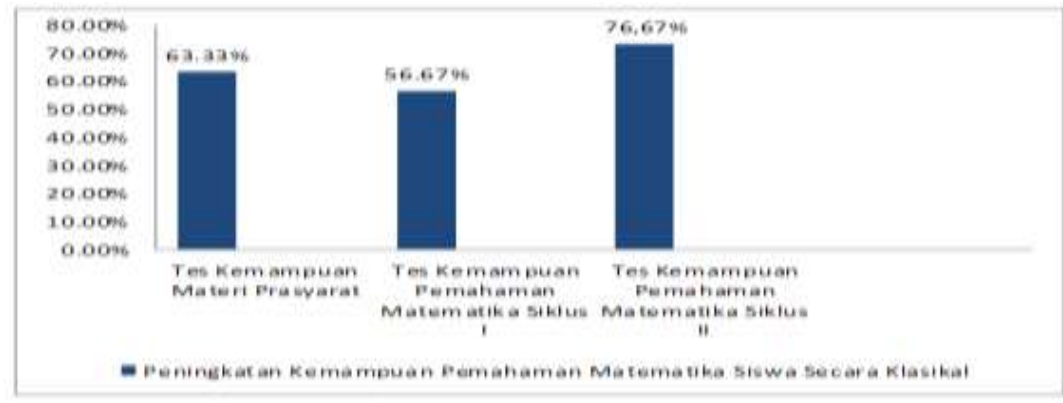

Gambar 6. Hasil Kemampuan Pemahaman Matematika Siswa Secara Klasikal

Gambar 6 di atas menunjukkan bahwa model pembelajaran kooperatif tipe Think-Pair-Share dapat meningkatkan kemampuan pemahaman matematika siswa kelas VII SMP Negeri 2 Pancur Batu.

\section{Penerapan Model Pembelajaran Kooperatif tipe Think-Pair-Share}

Penerapan dalam model pembelajaran kooperatif tipe Think-Pair-Share pada siklus I berjalan dengan baik namun masih terdapat kekurangan atau kelemahan dalam melaksanakan proses belajar mengajar sehingga dilanjutkan pada siklus II. Pelaksanaan siklus II dilaksanakan sesuai dengan tahapan yang terdapat pada siklus I.

Penerapan model pembelajaran kooperatif tipe Think-Pair-Share pada siklus II berjalan lebih baik dibandingkan siklus I. Dari hasil observasi yang

Cartesius: Jurnal Pendidikan Matematika Vol. 2, No. 1

CProdi Pendidikan Matematika Universitas Katolik Santo Thomas 
diperoleh menunjukkan mengalami perubahan yang sangat baik. Dengan adanya perubahan pada siklus II dapat disimpulkan bahwa penerapan model pembelajaran kooperatif tipe Think-Pair-Share sudah berjalan dengan baik sesuai dengan tahapan dan hasil yang diperoleh juga sudah mencapai indikator keberhasilan yang diharapkan.

\section{KESIMPULAN}

Berdasarkan hasil penelitian yang dikemukakan maka diambil kesimpulan yaitu sebagai berikut:

1. Tingkat kemampuan pemahaman matematika siswa kelas VII SMP Negeri 2 Pancur Batu dengan menggunakan model pembelajaran kooperatif tipe Think-Pair-Share meningkat dengan baik, hal ini dapat dilihat dengan hasil perolehan dari nilai tes kemampuan pemahaman matematika siswa siklus I dan siklus II yaitu 56,67\% menjadi 76,67\%.

2. Penerapan model pembelajaran kooperatif tipe Think-Pair-Share dapat dilihat setelah pembelajaran siklus I dan siklus II dilaksanakan.

a. Tingkat kemampuan materi prasyarat sebelum menerapkan model pembelajaran kooperatif tipe Think-Pair-Share diperoleh ketuntasan klasikal sebesar $63,33 \%$.

b. Tingkat kemampuan pemahaman matematika siswa siklus I diperoleh ketuntasan klasikal sebesar 56,67\%. Tingkat kemampuan pemahaman matematika siswa siklus II diperoleh ketuntasan klasikal sebesar 76,67\%. Dari hasil tersebut menunjukkan bahwa tingkat kemampuan pemahaman matematika siswa dari siklus I ke siklus II telah mengalami peningkatan yaitu sebesar $20 \%$.

c. Hasil observasi aktivitas guru siklus I diperoleh ketuntasan klasikal sebesar 57,14\%. Hasil observasi aktivitas guru siklus II diperoleh ketuntasan klasikal sebesar 77,14\%. Sedangkan hasil observasi aktivitas siswa siklus I diperoleh ketuntasan klasikal sebesar 61,42\%. Hasil observasi aktivitas siswa siklus II diperoleh ketuntasan klasikal sebesar $85,71 \%$.

Dari hasil data yang diperoleh, dapat disimpulkan bahwa dengan model pembelajaran kooperatif tipe Think-Pair-Share dapat meningkatkan

Cartesius: Jurnal Pendidikan Matematika Vol. 2, No. 1

CProdi Pendidikan Matematika Universitas Katolik Santo Thomas 
kemampuan pemahaman matematika siswa di kelas VII SMP Negeri 2 Pancur Batu.

\section{UCAPAN TERIMAKASIH}

Penulis menyampaikan terimakasih kepada Ibu Imelda, S.Pd., M.Pd. sebagai dosen pembimbing 1 dan Ibu Tetty Natalia Sipayung, S.Si., M.Pd. sebagai dosen pembimbing 2 yang telah mengarahkan dan membimbing penulis mulai dari awal penelitian hingga berakhirnya penelitian sehingga penulis dapat menuliskan artikel ini yang merupakan bagian dari hasil penelitian penulis. Penulis juga menyampaikan terimakasih kepada kepala program studi Pendidikan Matematika, dekan, dan rektor Universitas Katolik Santo Thomas atas dukungan yang diberikan kepada penulis.

\section{DAFTAR PUSTAKA}

[1] D. P. Sari, N. Nurochmah, H. Haryadi, and S. Syaiturjim, "Meningkatkan Kemampuan Pemahaman Matematis Melalui Pendekatan Pembelajaran Student Teams Achivement Division," J. Ris. Pendidik. Mat., Vol. 3, No. 1, pp. 16-22, 2016.

[2] Andriani, M. Ikhsan, and B. I. Anshari, "Peningkatan Kemampuan Pemahaman dan Motivasi Siswa SMP melalui Model Missouri Mathematics Project (MMP) dengan Menggunakan Game Matematika Online," J. Didakt. Mat., Vol. 3, No. 1, pp. 55-63, 2016.

[3] H. Kusmanto and I. Marliyana, "Pengaruh Pemahaman Matematika Terhadap Kemampuan Koneksi Matematika Siswa Kelas VII Semester Genap SMP Negeri 2 Kasokandel Kabupaten Majalengka," EduMa, Vol. 3, No. 2, pp. 61-75, 2014.

[4] D. Novitasari, "Pengaruh Penggunaan Multimedia Interaktif Terhadap Kemampuan Pemahaman Konsep Matematis Siswa," FIBONACCIJ. Pendidik. Mat. dan Mat., Vol. 2, No. 2, pp. 8-18, 2016.

[5] Elhefni, "Model Pembelajaran Kooperatif Tipe Think Pair Share Dan Hasil Belajar di Sekolah," TA'DIB, Vol. XVI, No. 2, pp. 303-319, 2011.

Cartesius: Jurnal Pendidikan Matematika Vol. 2, No. 1

CProdi Pendidikan Matematika Universitas Katolik Santo Thomas 